\title{
Effect of temperature on the aggregation of Skeletonema costatum (Bacillariophyceae) and the implication for carbon flux in coastal waters
}

\author{
Daniel C. O. Thornton*, Brenda Thake \\ School of Biological Sciences, Queen Mary and Westfield College, Mile End Road, London E1 4NS, United Kingdom
}

\begin{abstract}
Skeletonema costatum (Greville) Cleve was isolated from a mucilaginous algal bloom in the Northern Adriatic Sea during April 1993. In nitrate-limited continuous culture the formation of aggregations of cells was positively correlated with temperature. Raising the temperature from 10 to $20^{\circ} \mathrm{C}$ caused cells to aggregate without a change in culture biomass. Reducing the temperature to $10^{\circ} \mathrm{C}$ caused washout of the aggregates, again with no change in biomass. In batch culture there was a positive relationship between aggregate concentration and temperature at $10,15,20$ and $25^{\circ} \mathrm{C}$. Aggregates and the cell surface of $S$. costatum adsorbed Alcian blue, a stain for acid and sulphated polysaccharides. Disruption of the aggregates on addition of $0.2 \mathrm{M} \mathrm{Na}_{2}$ EDTA indicated that cross-linking between polysaccharides by divalent cations (probably $\mathrm{Ca}^{2+}$ in seawater) bound the aggregates together. Aggregates may form in situ under conditions of temperature increase and high phytoplankton biomass. Surface water temperature increased by $0.2^{\circ} \mathrm{C} \mathrm{d}^{-1}$ in the second half of July 1992 in the Northern Adriatic, coinciding with a chlorophyll a increase of 10 to $50 \mu \mathrm{g} \mathrm{l}^{-1}$. A temperature difference of $1.2^{\circ} \mathrm{C}$ was observed at 2 stations $4 \mathrm{~m}$ apart in May 1992 on either side of a plume front associated with the River Po; transfer of phytoplankton in eddies from cold to warm waters may lead to the formation of aggregates. Aggregate disruption may occur with the sinking of aggregates from surface waters to the relatively cool waters below the thermocline. The temperature decrease through the thermocline varied between 2.7 and $4.1^{\circ} \mathrm{C}$ in May 1992. The relationship between aggregation and temperature may be an important factor in determining the flux rate of fixed carbon and nutrients from the photic zone to deeper waters and the sea bed. Aggregated cultures had significantly higher sinking rates than unaggregated cultures.
\end{abstract}

KEY WORDS: Diatom - Aggregation - Temperature Continuous culture - Marine snow S Skeletonema costatum

\section{INTRODUCTION}

In both coastal seas and the open ocean macroscopic aggregates, known as marine snow, form from detritus, living organisms and inorganic matter. Aggregates are an ubiquitous feature of the water column in marine systems. Aggregates are also found in limnetic systems; Grossart \& Simon (1993) described the occurrence of lake snow in Lake Constance, Germany. The aggregation of cells in diatom blooms is an important

\footnotetext{
-Present address: Department of Biological Sciences, University of Essex, Colchester CO4 3SQ, United Kingdom.

E-mail:dan@essex.ac.uk
}

source of marine snow of potential global significance (Alldredge \& Silver 1988). Aggregation and the sinking of aggregates have been suggested to play a role in the life histories of diatoms (Smetacek 1985, Logan \& Alldredge 1989), representing the transition from a growing to a resting stage.

Aggregates are ecologically significant for 2 reasons: they function as transport agents and form microenvironments in the water column. Large $(>100 \mu \mathrm{M})$ particles sinking through the water column are responsible for most of the downward vertical mass flux in the sea (Fowler \& Knauer 1986). This mass flux or transport will result in the removal of carbon fixed in the photic zone from the sea surface to the sea bed. Sinking of 
aggregates leads to the removal of nutrients such as nitrogen and phosphorus from the photic zone. These elements are essential for the growth of phytoplankton. Aggregation increases the rate of downward flux of elements, as larger particles will sink through the water column faster than smaller particles of the same density. Mass sinking of diatoms is accelerated by cell protuberances and mucous secretions which lead to entanglement and aggregation. Aggregates tend to collect particulate material from the water column and may have sinking rates of up to $100 \mathrm{~m} \mathrm{~d}^{-1}$ (Smetacek 1985). Jackson (1995) emphasised the importance of the coagulation of algae in marine ecosystems and noted that aggregates are necessary to explain the disappearance of algae from the surface waters and their appearance in the benthos. The microenvironment within aggregates serves as a habitat containing enriched microbial communities in which the rates of processes such as photosynthesis, decomposition and nutrient regeneration occur at highly elevated levels (Alldredge \& Silver 1988). There are pronounced chemical gradients within this microenvironment; Shanks \& Reeder (1993) found strong reducing microzones in marine snow, even when the surrounding water column was well oxygenated.

The 4 major mechanisms which bring particles together in the ocean are Brownian motion, fluid shear, differential settlement and animal feeding (McCave 1984). Diatoms are too large to be affected by Brownian motion. A major feature of recent studies of diatom aggregation in the laboratory has been the measurement of coagulation efficiency or stickiness $(\alpha$, the probability that the cells will stick together on collision). Diatom aggregation may occur by 2 mechanisms: cell-cell binding as observed in Skeletonema costatum (Kiørboe \& Hansen 1993) or the binding of cells to transparent exopolymeric particles (TEP) produced by the diatoms. Cell-TEP binding has been shown to occur in Chaetoceros affinis (Kiørboe \& Hansen 1993) and Chaetoceros gracilis (Crocker \& Passow 1995). By carrying out flocculation experiments with mixtures of 2 species, Crocker \& Passow (1995) showed that there was preferential aggregation of some species and those with a high stickiness $(\alpha)$ occurred at higher frequencies in aggregates.

There have been many field observations of diatom aggregation and mass sinking. Alldredge \& Gotschalk (1989) followed the mass flocculation of diatom blooms in the surface waters of the Santa Barbara Channel, California, USA, during 1986 and 1988. The aggregates contained living diatoms, predominantly Chaetoceros sp. and Nitzschia sp.; 9 other diatom genera were present including Skeletonema sp. Alldredge \& Gotschalk (1989) found that the in situ settling velocity of aggregates, formed predominantly from Chaeto- ceros sp., was 2 orders of magnitude faster than unaggregated Chaetoceros sp. at $117 \pm 56 \mathrm{~m} \mathrm{~d}^{-1}$ (mean \pm SD). Riebesell (1991a, b) monitored aggregates at a fixed station in the southern North Sea for $6 \mathrm{wk}$. The aggregates were mainly formed from diatoms, including Chaetoceros sp., Nitzschia sp. and Skeletonema costatum. Physical coagulation processes, rather than inorganic nutrient limitation, appeared to control the termination of the bloom. The aggregates were mucus rich, composed of algal and detrital particles, with large numbers of attached bacteria (Riebesell 1991b). In both 1990 and 1991 the collapse of a spring bloom of S. costatum in the Firth of Clyde, Scotland was associated with the sedimentation of aggregates dominated by $S$. costatum (Napier 1995). Stachowitsch et al. (1990) suggested that the mucous aggregates often observed during summer in the Northern Adriatic are initially produced by diatoms.

During a study investigating the cause of mucilaginous blooms in the Northern Adriatic we observed that batch cultures of Skeletonema costatum removed from relatively cool culture conditions $\left(10\right.$ to $\left.15^{\circ} \mathrm{C}\right)$ to room temperature $\left(20\right.$ to $25^{\circ} \mathrm{C}$ ) formed visible aggregates ( $<1 \mathrm{~mm}$ in diameter). There have been no laboratory studies on the effect of temperature on the aggregation of diatoms. The aim of this work was to test the hypothesis that aggregation was a direct consequence of temperature rise on the diatom. The waters of coastal seas, including the Northern Adriatic, may be considered as a mosaic of water masses with different properties. River plumes, areas of mixing by tidal currents and stratified areas contribute to this mosaic of water masses between which there are often sharp gradients of temperature on horizontal and vertical scales. The transfer of phytoplankton biomass across sharp gradients may lead to aggregation on transfer to warmer waters or disaggregation on transfer to cooler waters.

\section{METHODS}

Organism. Skeletonema costatum (Greville) Cleve (Bacillariophyceae) was isolated from a bloom in the Northern Adriatic in April 1993. The water temperature was $10^{\circ} \mathrm{C}$. At this time S. costatum was the dominant component of the microflora $>99 \%$ of the cell density) and mucilage was observed in the water column. S. costatum has been observed in previous studies (Stachowitsch et al. 1990) in association with mucous aggregates in the Northern Adriatic. S. costatum often dominates the spring bloom in coastal waters (Han et al. 1992).

Medium. The broad spectrum artificial seawater of Harrison et al. (1980) was used to grow Skeletonema costatum in batch and continuous culture. To ensure 
there was a single nitrogen source, $\mathrm{Fe}\left(\mathrm{NH}_{4}\right)_{2}\left(\mathrm{SO}_{4}\right)_{2} \cdot 6 \mathrm{H}_{2} \mathrm{O}$ was replaced with $\mathrm{FeCl}_{3}$ to produce the same $\mathrm{Fe}$ concentration $(6.6 \mu \mathrm{M})$. Silicon $(141 \mu \mathrm{M})$ was provided as $\mathrm{Na}_{2} \mathrm{SiO}_{3} \cdot 5 \mathrm{H}_{2} \mathrm{O}$, phosphorus as $\mathrm{Na}_{2}$ glyceroPO $\mathrm{P}_{4}$ and nitrogen as $\mathrm{NaNO}_{3}$. Concentrations of $\mathrm{N}$ and $\mathrm{P}$ were manipulated and are given in the appropriate section.

Batch culture. The batch cultures used to inoculate the chemostats were grown under continuous light at $10^{\circ} \mathrm{C}$ with a photon flux density (p.f.d.) of $70 \mu \mathrm{mol} \mathrm{m} \mathrm{m}^{-2}$ $\mathrm{s}^{-1}$ with nitrate and phosphate concentrations of $100 \mu \mathrm{M}$.

Continuous culture. Continuous cultures such as chemostats are open systems in which growth rates $(\mu)$ are controlled by the rate of supply of a limiting nutrient. The rate of biomass change is given by:

$$
\frac{\mathrm{d} X}{\mathrm{~d} t}=\mu X-D X
$$

where $X$ is biomass concentration, $D$ is dilution rate and $t$ is time. At steady state, $X$ is constant and therefore $\mu=D$. The cells produced at steady state are of similar biochemical composition and physiological state. The theory of chemostats has been reviewed by Tempest (1970) and their application to algal cultures by Fogg \& Thake (1987). Chemostat cultures were used to test the following hypotheses:

Hypothesis 1: Aggregation is a function of the rate of temperature increase. Once the organism has adapted to the higher temperature, the aggregates will wash out at the dilution rate.

Hypothesis 2: Aggregate concentration is propor tional to temperature. Aggregate concentration will increase with a rise in temperature and decrease with a drop in temperature.

The chemostat system used in this work has been described by several workers (Wymer \& Thake 1980, Santillo 1993, Thornton 1996). Cultures of 1.5 l were grown in $2 \mathrm{l}$ glass reaction vessels. Medium was supplied via silicone rubber tubing through a 22-channel Carlo Erba peristaltic pump from a medium reservoir of Pyrex glass. Overflow was collected via a glass tube and passed to a waste container. Filtered air from a compressor was supplied to the cultures to produce a slight positive pressure which ensured that excess culture was removed via the overflow, $\mathrm{CO}_{2}$ supply was maintained and that the culture was mixed. Stirring was provided by magnetic stirrers and magnetic followers at a rate of $150 \mathrm{rpm}$. Temperature of the culture was maintained by a temperature controlled $\left( \pm 0.5^{\circ} \mathrm{C}\right)$ water jacket connected to flow heater/cooler systems (Grant Instruments Ltd, Cambridge, UK). Continuous light was provided on 2 sides of the culture by two $4 \mathrm{ft}$ (ca $1.2 \mathrm{~m}$ ) $40 \mathrm{~W}$ fluorescent tubes (F40W/DL-RS, Sylvania, UK). Photon flux density at the surface of the vessels was 80 to $110 \mu \mathrm{mol} \mathrm{m} \mathrm{m}^{-2} \mathrm{~s}^{-1}$. If light was passed through the culture from 1 side, the p.f.d. in the centre of the culture was 40 to $70 \mu \mathrm{mol} \mathrm{m} \mathrm{m}^{-2} \mathrm{~s}^{-1}$, depending on the culture conditions. Actual p.f.d. in the centre of the vessels would be higher, as light was entering the culture vessels from 2 sides. Light saturation of growth ( $\mu=2.9 \mathrm{~d}^{-1}$ ) was observed at 25 to $30 \mu \mathrm{mol} \mathrm{m} \mathrm{m}^{-2} \mathrm{~s}^{-1}$ for the isolate used in this work (Santillo 1993, pers. comm.).

Cell counts. Samples were taken with sterile pipettes from sampling ports of the chemostats and were preserved with Lugol's iodine (Parsons et al. 1984). Counts were made in a haemocytometer with modified FuchsRosenthal ruling. Aggregates were broken up without cell damage by passing through a 23 gauge hyperdermic needle. Skeletonema costatum is a chain-forming diatom; therefore, counts were made of cell chains rather than individual cells, as these were the randomly distributed units on the haemocytometer. The mean cell chain length was less than 2 cells per chain. 400 cell chains were counted to give a precision $(95 \%$ confidence) of $\pm 10 \%$ (Guillard 1973)

Bacteria were stained with the DNA specific stain DAPI (4'6-diamidino-2-phenylindole dihydrochloride) and filtered onto a membrane filter (Porter \& Feig 1980). The DNA-DAPI complex fluoresces bright blue, producing a glow which allows cells smaller than the limit of resolution (generally $<1 \mu \mathrm{m}$ ) to be seen and counted under fluorescence with the light microscope.

Aggregate analysis. 100 aggregates were counted (giving a standard deviation of \pm 10 aggregates) using a Sedgewick-Rafter counting slide and a light microscope.

The chelating agent Na ${ }_{2}$ EDTA (ethylenediaminetetraacetic acid disodium salt) was used to test the hypothesis that binding between Skeletonema costatum cells to form aggregates is facilitated by divalent cations such as $\mathrm{Ca}^{2+}$ and $\mathrm{Mg}^{2+}$. If cations are involved in the binding, then the addition of $\mathrm{Na}_{2}$ EDTA will cause the disruption of the aggregates. $1 \mathrm{ml}$ of $0.8 \mathrm{M}$ $\mathrm{Na}_{2}$ EDTA was added to $3 \mathrm{ml}$ of Lugol preserved culture to produce a final concentration of $0.2 \mathrm{M}$.

Sinking rates. Sinking rates were measured at room temperature (ca $20^{\circ} \mathrm{C}$ ) in $25 \mathrm{ml}$ glass burettes using a method based on that of Bienfang (1981). The burettes were filled at $t_{0}$ (time zero) and the optical density of the culture was measured at $664 \mathrm{~nm}$ spectrophotometrically. The burettes were covered in aluminium foil to exclude light and left in a vertical position for several hours, ensuring that a significant portion of the biomass remained in suspension. At the end of the experiment $\left(t_{t}\right)$ the optical density of $4 \mathrm{ml}$ from the bottom of the burette was measured. This $4 \mathrm{ml}$ included the settled out biomass. Settling rate was calculated from the following equation:

$$
V=\frac{B_{\mathrm{s}}}{B_{\mathrm{t}}} \times \frac{L}{t}
$$


where $B_{\mathrm{t}}=$ total biomass $=\left(b_{\mathrm{t}} \times v_{\mathrm{t}}\right) ; B_{\mathrm{s}}=$ settled biomass $=\left(b_{\mathrm{s}} \times v_{\mathrm{s}}-b_{\mathrm{t}} \times v_{\mathrm{s}}\right)\left(b_{\mathrm{t}}=\right.$ biomass $\mathrm{ml}^{-1}$ at start, $v_{\mathrm{t}}=$ total volume in burette, $b_{\mathrm{s}}=$ biomass $\mathrm{ml}^{-1}$ at end of settling time, $v_{s}=$ settled volume removed from the burette [4 ml]); $L=$ depth of liquid in burette, $t=$ settling time (h).

To test the hypothesis that aggregated Skeletonema costatum would sink faster than less aggregated $S$. costatum an aggregated culture was divided into 2 aliquots, one of which was passed through a hyperdermic needle to reduce the number of aggregates. This produced $3100 \pm 390$ aggregates $\mathrm{ml}^{-1}$ in the aggregated and $690 \pm 200$ aggregates in the less aggregated aliquot (mean $\pm \mathrm{SD}, \mathrm{n}=3$ ). There was a significant difference between the mean number of aggregates in the 2 treatments $(p<0.001$, Student's $t$ test). A settling experiment was set up with 11 replicates from each aliquot.

Batch experiment. Skeletonema costatum was grown in a 1 l culture with nitrate and phosphate concentrations of $500 \mu \mathrm{M}$. Aliquots $(50 \mathrm{ml})$ of cultures in exponential phase were placed in $60 \mathrm{ml}$ tissue culture vessels in either the light $\left(70 \mu \mathrm{mol} \mathrm{m} \mathrm{m}^{-2} \mathrm{~s}^{-1}\right)$ or dark (by wrapping in aluminium foil) and incubated for $50 \mathrm{~h}$. The diatoms were maintained in suspension by swirling the bottles 3 times a day. Incubations were carried out in triplicate at 4 temperatures $(10,15,20$ and $25^{\circ} \mathrm{C}$ ). The bottles were sampled for cell counts and aggregate concentrations.

Chemostat experiments. The chemostats were grown under nitrate limitation as this was found to be the nutrient limiting algal growth during field bioassays carried out in 1992 (data not presented). Chemostats were used in the experimental work as they allowed for control of growth rates. Specific chemostats are referred to by name (N1-N14). All chemostats were grown at a dilution rate of $0.3 \mathrm{~d}^{-1}$ with nitrate and phosphorus concentrations of $100 \mu \mathrm{M}$ and an initial temperature of $10^{\circ} \mathrm{C}$. Small samples, such as those used for cell counts, were removed from the chemostat with a sterile pipette via a sampling port in the lid of the vessel. Larger samples were taken via the overflow by tilting the chemostat vessel. The maximum volume removed from the vessel at 1 sampling was $250 \mathrm{ml}$

Data analysis. Statistical analysis was carried out on logarithmic transformed data $\left[X^{\prime}=\log (X+1)\right]$ to remove heteroscedasticity from the data set. Linear regressions were fitted using Fig.P (Fig.P Sofware Corporation 1992) and multiple comparisons were made by analysis of variance (ANOVA) followed by post hoc Tukey tests (SYSTAT Products 1997). Data in the figures are presented in an untransformed state. Percentage data was arcsine transformed before analysis; the back transformed data are presented.

\section{RESULTS}

\section{Batch experiment}

Aggregate concentration increased with temperature (Fig. 1a) in both the light and dark incubated Skeletonema costatum cultures. In the light the mean
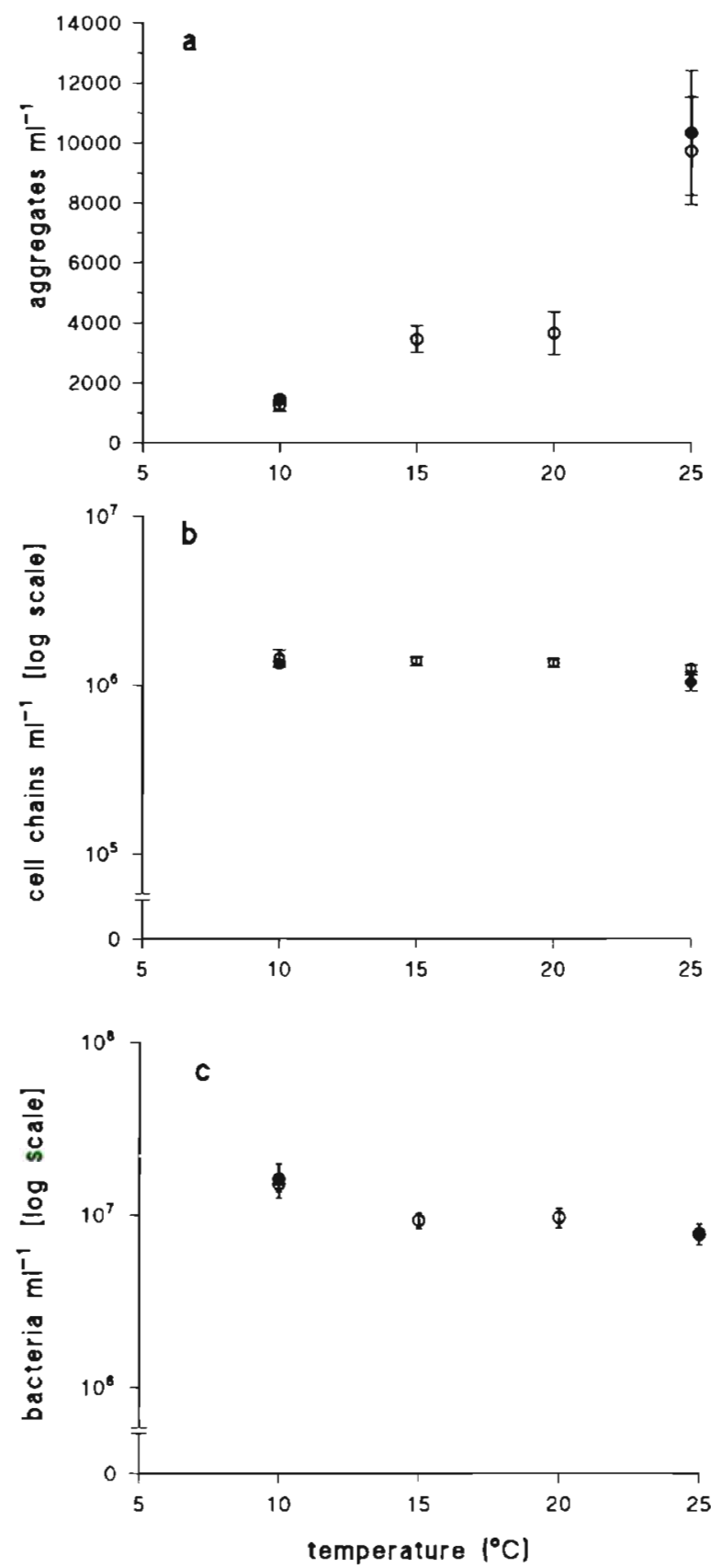

Fig. 1. Skeletonema costatum. Aggregation $50 \mathrm{~h}$ after transfer from $10^{\circ} \mathrm{C}$ to 1 of 4 temperatures. (a) Aggregate concentration, (b) cell chain concentration and (c) bacteria concentration. Incubations were carried out in the light (O) and dark ( $\bullet$ Values are means $\pm \mathrm{SE}(\mathrm{n}=3)$ 
concentration at $10^{\circ} \mathrm{C}$ was $1260 \pm 200$ aggregates $\mathrm{ml}^{-1}$ (mean $\pm \mathrm{SE}, \mathrm{n}=3$ ) increasing to $9740 \pm 1800$ aggregates $\mathrm{ml}^{-1}$ at $25^{\circ} \mathrm{C}$ (Fig. 1a). There was a significant difference between aggregate concentration at the 4 temperatures in the light $\left(F_{3,8}=21.2, p<0.001\right)$. The increase in aggregate concentration was not due to an increase in growth rate at higher temperatures resulting in a higher biomass. Yields were the same after $50 \mathrm{~h}$ (Fig. 1b), irrespective of temperature or light regime. Therefore, the increase in aggregate concentration at higher temperatures was due to a greater relative aggregation of the biomass. There was a significant difference in the yield of bacteria $\left(F_{3,7}=5.68\right.$, $\mathrm{p}<0.05$ ) at the 4 temperatures in the light. A post hoc Tukey test showed that the significant $(p<0.05)$ source of variation was between cultures at the 2 extremes of the temperature range, 10 and $25^{\circ} \mathrm{C}$. At $10^{\circ} \mathrm{C}$ the mean number of bacteria was $1.2 \times 10^{7}$ bacteria $\mathrm{ml}^{-1}$, and at $25^{\circ} \mathrm{C}$ there were $7.7 \times 10^{6}$ bacteria $\mathrm{ml}^{-1}$. A significant linear regression was fitted to aggregate concentration against time $\left(A=b T+c\right.$, where $A$ is aggregates $\mathrm{ml}^{-1}$ and $T$ is temperature $\left.\left[{ }^{\circ} \mathrm{C}\right]\right)$; the results of this fit were $A=513 \mathrm{~T}-4450\left(\mathrm{r}^{2}=0.69 ; \mathrm{p}<0.001\right.$, Table B.17 in Zar 1996).

\section{Chemostat experiments}

Increase in temperature

Production of aggregates in chemostats N1-N4 is shown in Fig. 2. When temperature was stepped up to 20 from $10^{\circ} \mathrm{C}$, there was a highly significant $\left(F_{1,36}=\right.$ 18.3, $\mathrm{p}<0.001$ ) increase in aggregate concentration (Fig. 2a) from $2870 \pm 391$ (mean $\pm \mathrm{SE}, \mathrm{n}=24$ ) to 22600 $\pm 1720(\mathrm{n}=24)$ aggregates $\mathrm{ml}^{-1}$. A post hoc Tukey test showed that the source of this variation was between sampling points before and after Day 50, the day on which the temperature was raised $(p<0.05)$. The sample on Day 50 was taken before the temperature was raised. The post hoc Tukey test showed that there was no significant difference between aggregate concentrations on different days at either 10 or $20^{\circ} \mathrm{C}$. The increase in aggregate concentration was not due to an increase in cell concentration (Fig. 2b). There was a highly significant variation between aggregate concentration normalised to biomass with time $\left(F_{11,36}=\right.$ 14.3, $\mathrm{p}<0.001$ ).

Fig. 3 shows the effect of raising the temperature from 10 to $20^{\circ} \mathrm{C}$ and from 20 to $30^{\circ} \mathrm{C}$. Fig. 3a shows that there was a significant difference between the aggregation concentration at 10 and $20^{\circ} \mathrm{C}$, but not between 20 and $30^{\circ} \mathrm{C}$. There was a highly significant difference between aggregate concentration with time $\left(F_{9,40}=\right.$ 8.97. $\mathrm{p}<0.0001$ ) (Fig. 3b). A post hac Tukey test
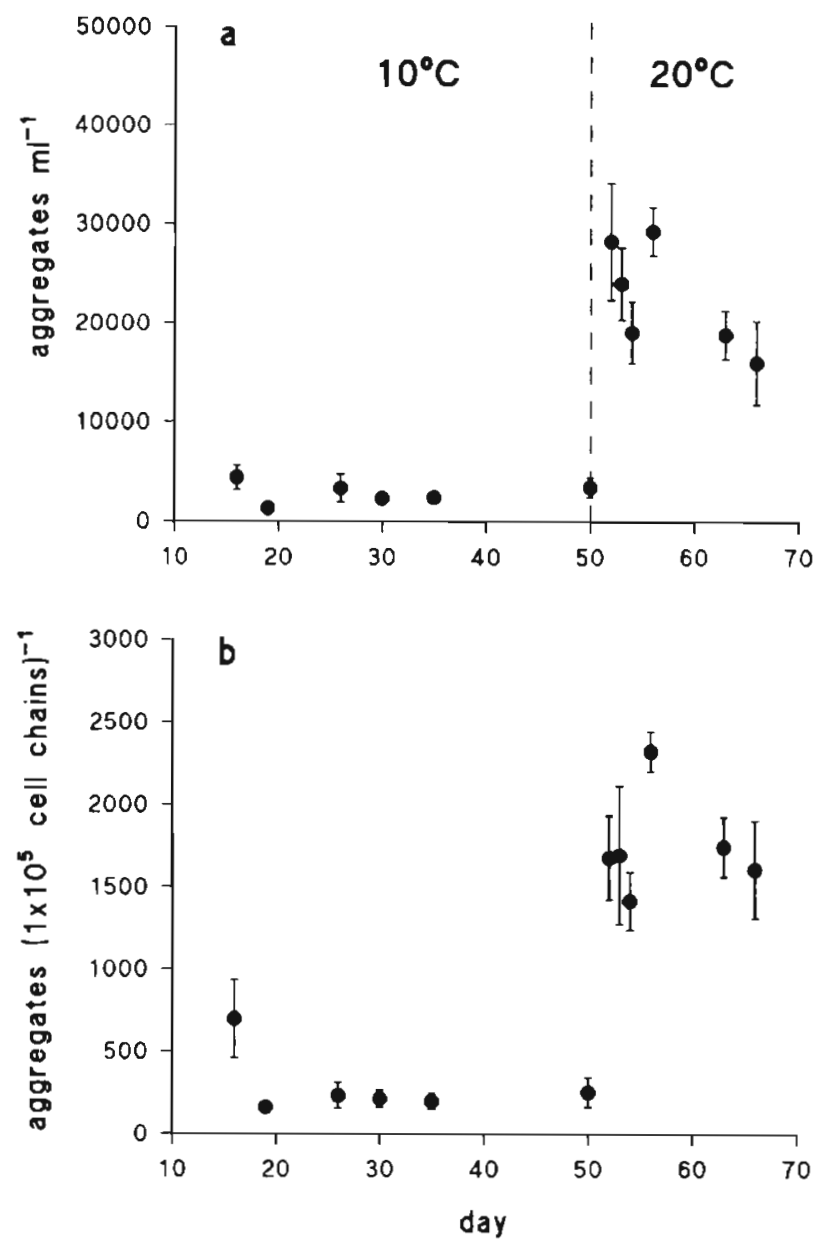

Fig. 2. Skeletonema costatum. Production of aggregates in nitrogen-limited continuous cultures (N1-N4) at 10 and $20^{\circ} \mathrm{C}$ with a dilution rate of $0.3 \mathrm{~d}^{-1}$. (a) Aggregate production against time. Values are means $\pm \operatorname{SE}(n=4)$. (b) Aggregate production normalised to cell chain concentration against time. Values are means $\pm \mathrm{SE}(\mathrm{n}=4)$

showed that the source of variation was between $10^{\circ} \mathrm{C}$ and the other temperatures $\left(20\right.$ and $\left.30^{\circ} \mathrm{C}\right)(\mathrm{p}<0.05)$. There was no significant difference between aggregate concentrations at 20 and $30^{\circ} \mathrm{C}$.

Increase in temperature followed by a decrease

An increase in temperature from 10 to $20^{\circ} \mathrm{C}$ followed by a decrease in temperature back to $10^{\circ} \mathrm{C}$ resulted in a higher aggregate concentration at $20^{\circ} \mathrm{C}$, with a return to the original aggregate concentration after the decrease in temperature (Fig. 4). At $10^{\circ} \mathrm{C}$ there were $1010 \pm 213$ (mean $\pm \mathrm{SE}, \mathrm{n}=30$ ) aggregates $\mathrm{ml}^{-1}$, increasing to $3390 \pm 704(\mathrm{n}=15)$ aggregates $\mathrm{ml}^{-1}$ at $20^{\circ} \mathrm{C}$ and decreasing to $798 \pm 104(\mathrm{n}=10)$ aggregates $\mathrm{ml}^{-1}$ when the temperature was dropped back to $10^{\circ} \mathrm{C}$. A 

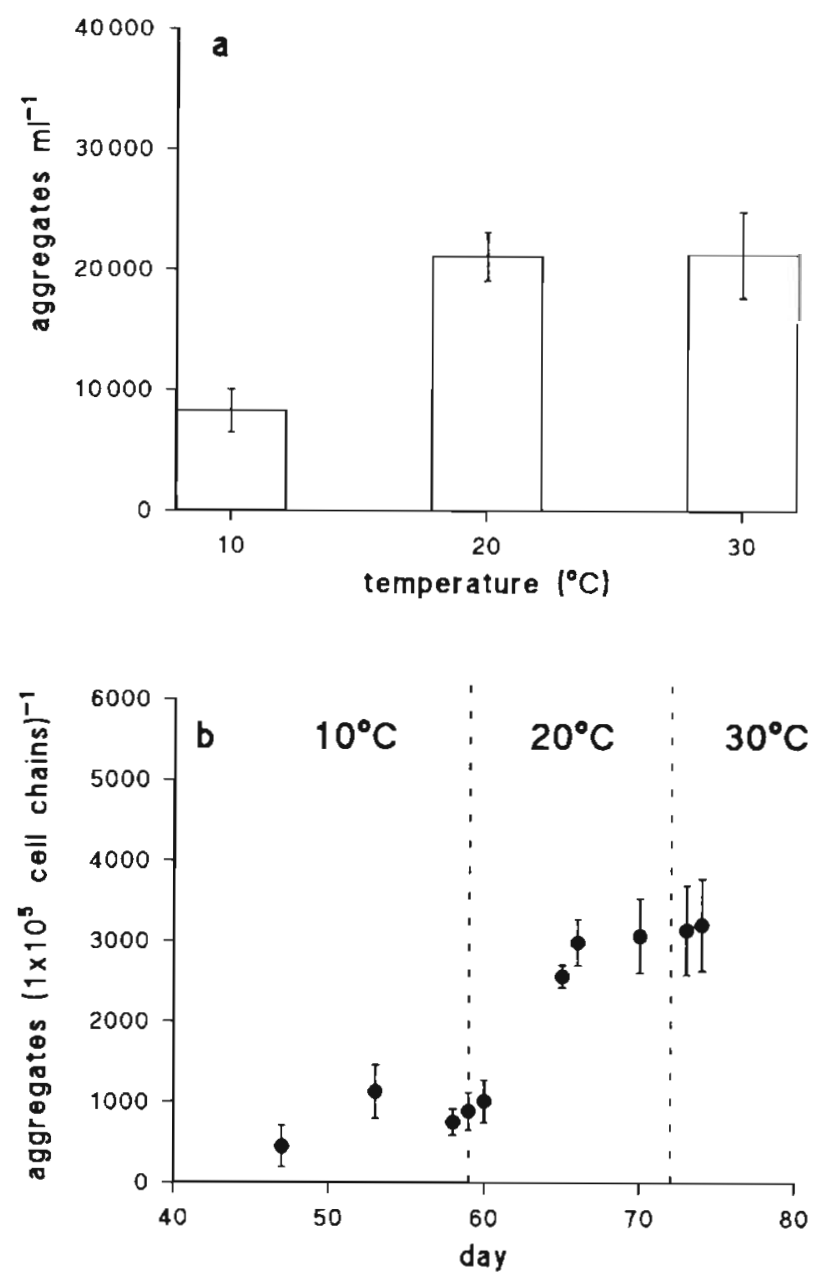

Fig. 3. Skeletonema costatum. Aggregate production in nitrogen-limited continuous cultures (N5-N9) grown at a dilution rate of $0.3 \mathrm{~d}^{-1}$ (a) Aggregate concentration at $10(\mathrm{n}=15), 20$ $(\mathrm{n}=20), 30^{\circ} \mathrm{C}(\mathrm{n}=5)$. Values are means $\pm \mathrm{SE}$. (b) Aggregate concentration normalised to cell chain concentration with time. Values are means $\pm \mathrm{SE}(\mathrm{n}=5)$

post hoc Tukey test showed that all the significant $(\mathrm{p}<$ $0.05)$ variation lay between aggregate concentrations at 10 and $20^{\circ} \mathrm{C}_{i}$ there was no significant difference between aggregate concentrations at $10^{\circ} \mathrm{C}$ on either side of the $20^{\circ} \mathrm{C}$ period.

\section{Relationship between aggregate concentration and} temperature

The relationship between mean daily temperature and aggregate concentration in chemostat N12 is shown in Fig. 5. Results from correlation analysis (Table 1) showed that there was a significant positive relationship between aggregate concentration and mean daily temperature, except in chemostat N10.

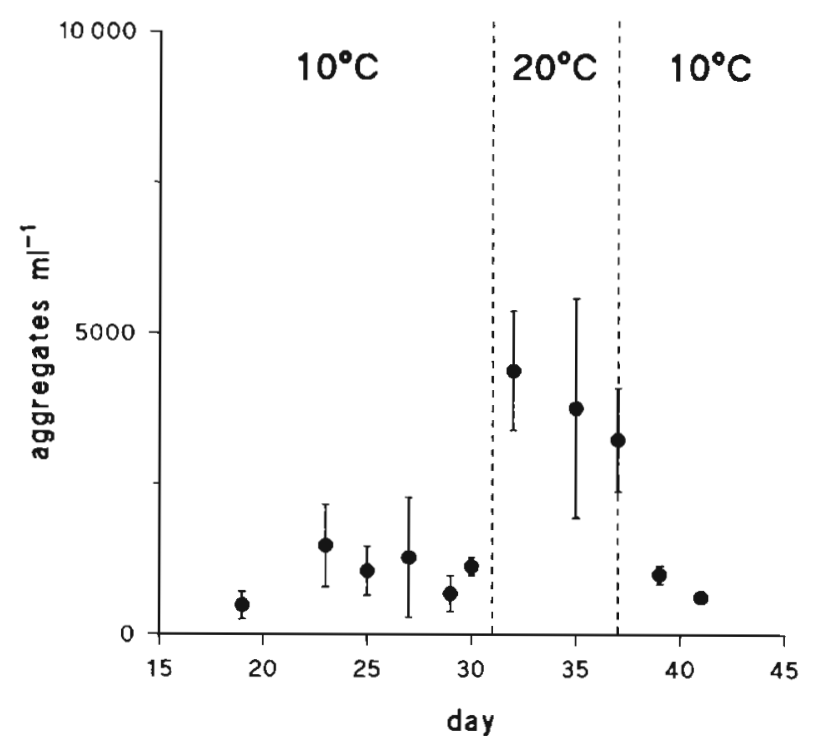

Fig. 4. Skeletonema costatum. Production of aggregates in nitrogen-limited continuous cultures (N10-N14) at 10 and $20^{\circ} \mathrm{C}$ with a dilution rate of $0.3 \mathrm{~d}^{-1}$. Values are means $\pm \mathrm{SE}$ $(n=5)$

\section{Properties of the aggregates}

The aggregates were relatively small, as indicated by the high concentrations of aggregates $\mathrm{ml}^{-1}$. Mean aggregate length was $75 \pm 25 \mu \mathrm{m}( \pm \mathrm{SD})$. Aggregates were composed of short chains of Skeletonema costatum. The aggregates were irregular with a dense core and a loose outer edge from which distinct cell chains

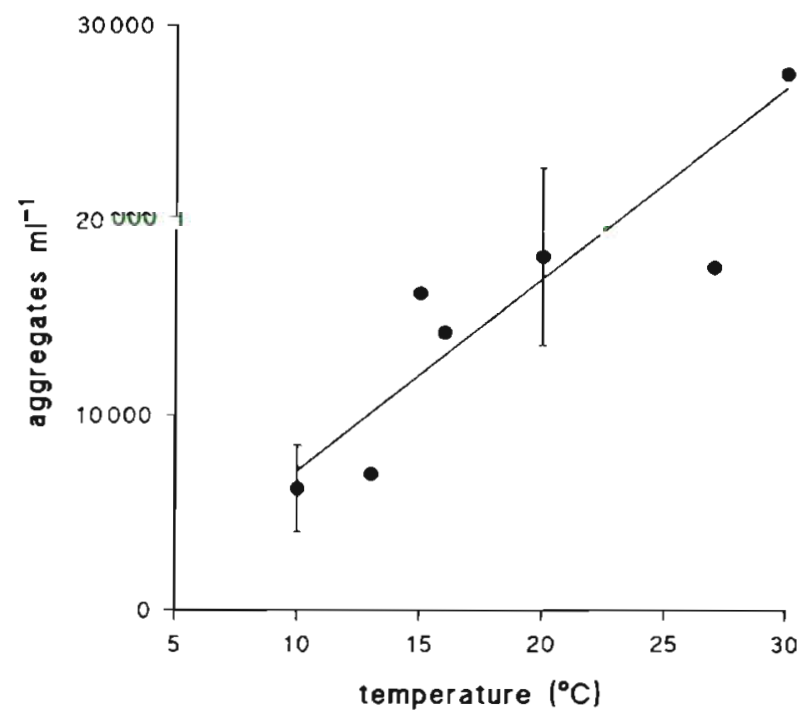

Fig. 5. Skeletonema costatum. Relationship between mean daily temperature and aggregate concentration in a nitrogenlimited continuous culture (N12). Values are means $\pm \mathrm{SE}$ $(n=1-4)$ 
Table 1. Skeletonema costatum. Positive correlation between mean daily temperature and aggregate number in nitratelimited chemostats (N10-N14). Correlation coefficients were calculated using Spearman's coefficient of rank correlation. Significance of the correlations was obtained from Table C.11 in Rees (1987) where $n=12$. Significance were ranked as follows: not significant (-), significant ("), and highly significant ( $\cdots$ )

\begin{tabular}{|c|c|c|}
\hline Chemostat & $\begin{array}{l}\text { Correlation } \\
\text { coefficient }\end{array}$ & $\begin{array}{c}\text { Significance } \\
\text { level }(p)\end{array}$ \\
\hline N10 & 0.37 & $>0.05$ \\
\hline N11 & 0.57 & $<0.05$ \\
\hline N12 & 0.95 & $<0.005 \cdots$ \\
\hline N13 & 0.78 & $<0.005 \cdots$ \\
\hline N14 & 0.90 & $<0.005 \cdots$ \\
\hline
\end{tabular}

projected (Fig, 6). There was no visible extracellular matrix holding the cells together. Staining with Alcian blue revealed a faint halo of blue around cell chains.

The addition of $\mathrm{Na}_{2}$ EDTA $(0.2 \mathrm{M})$ to aggregated samples caused disaggregation. The mean reduction

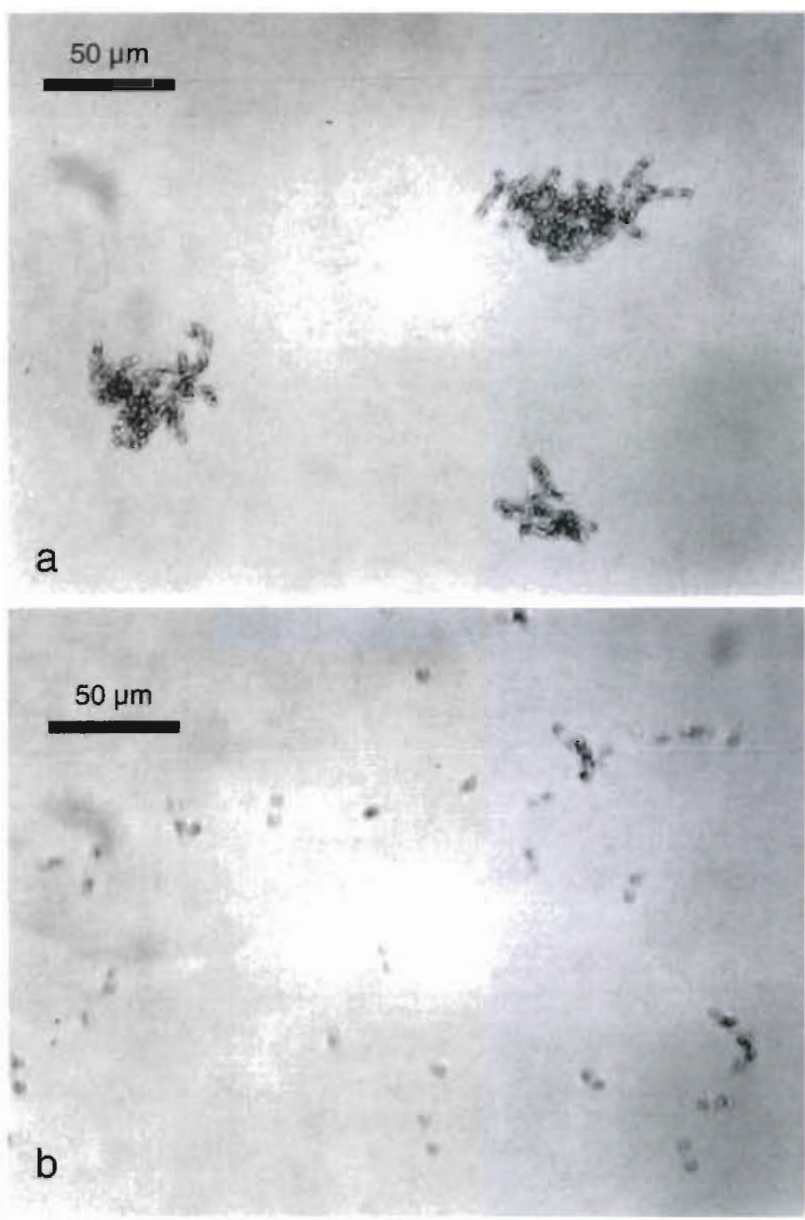

Fig. 6. Skeletonema costatum. Light micrograph taken from a nitrate-limited chemostat culture (N9). (a) Aggregated at $20^{\circ} \mathrm{C}$ and (b) unaggregated at $10^{\circ} \mathrm{C}$ in the number of aggregates was $74 \pm 4 \%$ (mean $\pm \mathrm{SE}$, $\mathrm{n}=3$ ). The addition of $\mathrm{Na}_{2}$ EDTA also caused lysis of some cells, the break-up of aggregates was a function of cell lysis as well as the chelation of divalent cations. $\mathrm{Na}_{2}$ EDTA caused a mean reduction in cell chain numbers of $24 \pm 1 \%$ (mean $\pm \mathrm{SE}, \mathrm{n}=3$ ).

Aggregated cultures had a faster sinking rates than cultures in which aggregate concentration had been reduced ( $p<0.001$, Student's $t$-test). The mean settling rates were $0.62 \pm 0.03 \mathrm{~cm} \mathrm{~h}^{-1}$ in aggregated and $0.37 \pm$ $0.02 \mathrm{~cm} \mathrm{~h}^{-1}$ (mean $\pm \mathrm{SE}, \mathrm{n}=11$ ) in unaggregated cultures. The settling rate in aggregated culture was almost twice that in unaggregated culture at 0.15 and $0.09 \mathrm{~m} \mathrm{~d}^{-1}$ respectively.

\section{DISCUSSION}

Aggregate concentration was positively correlated with temperature in batch cultures of Skeletonema costatum incubated at $10,15,20$ and $25^{\circ} \mathrm{C}$. In the chemostat cultures, the aggregation of $S$. costatum was positively correlated with temperature; a rise in temperature caused an increase in aggregate concentration which decreased when temperature was lowered (hypothesis 2). As aggregate concentration reached a steady state as well as cell numbers, aggregation must have occurred at approximately the same rate as cell growth, which was dictated by the dilution rate of the chemostat. Therefore continued aggregation was dependent on continued growth. New aggregates could only form with the generation of new biomass, unless there was a rise in temperature. Aggregation was not a function of rate of temperature increase (hypothesis 1) as the aggregates did not wash out at the dilution rate once temperature had stabilised. The formation of new aggregates was likely to be a result of growth within the aggregates and the attachment of free cell chains until such a size was reached that the shear stress within the chemostat caused fragmentation into 2 or more smaller aggregates.

To increase the chance of aggregation there must either be an increased probability of 2 chains colliding, an increase in the probability $(\alpha)$ of 2 cell chains becoming stuck together on collision, or a combination of the 2 processes. As there was no increase in cell numbers with temperature, the observed increase in aggregation was due to an increase in $\alpha$. In non-axenic cultures of Skeletonema costatum, $\alpha$ was measured as 0.02 to 0.25 by Kiørboe \& Hansen (1993); the wide range of observed values show that there is a potential for significant changes in $\alpha$. An increase in $\alpha$ must have been due to a change in the surface properties of the cells. No changes in cell size with increasing temperature were observed during this work. We propose that 
the surface of the cells became more sticky with increased temperature. The cationic dye Alcian blue may be used to stain negatively charged polysaccharides (Decho 1990, Alldredge et al. 1993). In this work both aggregates and free suspensions of $S$. costatum were observed to take up the stain, which was clearly associated with the cell surface. The addition of $\mathrm{Na}_{2}$ EDTA caused aggregates to break up; $\mathrm{Na}_{2}$ EDTA is a strong chelating agent, known to disrupt cationic bridges $\left(\mathrm{Ca}^{2+}\right.$ and $\mathrm{Mg}^{2+}$ ) between exopolymers (Decho 1990). Alldredge et al. (1993) found that laboratorymade aggregates of Chaetoceros gracilis broke up immediately on suspension in $1 \mathrm{M}$ EDTA. Break-up of aggregates occurred at $0.2 \mathrm{M} \mathrm{Na}_{2}$ EDTA in this work. Alldredge et al. (1993) do not comment on the effect of EDTA on cell integrity, but it is highly likely that cell lysis occurred within the aggregates, which may have caused some of the observed disaggregation. In this work the lysis of cells was insufficient to account for the $74 \%$ reduction in aggregate concentration and it was concluded that the cationic bridges binding the cells together were disrupted.

The turbulent regime within the chemostats was one of the factors dictating the size of the aggregates formed within the chemostat system. The stirring regime and vessel size of all the chemostats was equali therefore, it was unlikely that there were any differences in turbulence between chemostats. An increase in temperature will result in a decrease in the viscosity of the medium and a resulting increase in turbulence; therefore, the contact rate between cell chains will increase. This was not an important factor in this investigation owing to the high degree of turbulence imparted by the vigorous mixing regime within the chemostats. There was no significant difference in aggregate size at different temperatures. Owing to the vigorous mixing regime aggregates were relatively small, mean aggregate length was $75 \pm 25 \mu \mathrm{m}( \pm \mathrm{SD})$. In situ turbulence is likely to be lower than that in the chemostats; therefore, it is likely that larger aggregates will form.

Bacteria were present in the isolate from the Adriatic Sea. In the batch experiment there were significantly fewer bacteria in cultures at $25^{\circ} \mathrm{C}$ compared to $10^{\circ} \mathrm{C}$; the greatest aggregation occurred at $25^{\circ} \mathrm{C}$. In batch culture the presence or absence of bacteria did not effect growth of Skeletonema costatum. We have demonstrated that the growth rates of axenic batch cultures did not have significantly different growth rates from cultures with natural background levels of bacteria or cultures to which up to 50 times the background concentration of bacteria were added after concentration through a flow cell (data not presented). These experiments showed no relationship between aggregate formation and presence or absence of bac- teria. Other work has shown that bacteria were not important during the aggregation of $S$. costatum; Kiørboe et al. (1990) found that the stickiness of $S$. costatum was not dependent on bacterial numbers or the ratio of bacterial numbers to algal biomass in batch cultures.

Skeletonema costatum used in this work was isolated from the Northern Adriatic Sea, where we observed temperature gradients in both time and space. A combination of a high phytoplankton biomass and rapid temperature change may lead to aggregation in situ. Field observations in July 1992 showed a rapid increase in surface water temperature during the second half of July $\left(0.2^{\circ} \mathrm{C} \mathrm{d}^{-1}\right)$ from 25 to $28.4^{\circ} \mathrm{C}$. There were sharp thermal gradients on horizontal scales. A plume front was observed in May 1992 off the river Po delta in the Northern Adriatic; there was a $1.2^{\circ} \mathrm{C}$ difference in surface temperature at 2 stations $4 \mathrm{~m}$ apart on either side of the front. Phytoplankton carried across the boundary within small eddies from cold to warm would be exposed to rapid temperature increase. Even greater thermal gradients were observed across thermoclines measured in the Northern Adriatic in May 1992. The decrease in temperature with depth at the thermocline was between 2.7 and $4.1^{\circ} \mathrm{C}$. The sinking of aggregates through the thermocline may lead to their disaggregation.

Associated with the temperature rise in July 1992 was an increase in chlorophyll a (chl a) from 10 to $50 \mu \mathrm{g} \mathrm{l}^{-1}$, which indicated an increase in cell density and therefore a greater potential for contact between cells and thus aggregation. In the chemostat cultures chl a concentrations ranged between 20 to $50 \mu \mathrm{g} \mathrm{l}^{-1}$, indicating that the in situ biomass was of a sufficient density to aggregate with an increase in temperature. Exceptionally high chl a concentrations have been recorded in the Northern Adriatici in 1984 concentrations up to $850 \mu \mathrm{g} \mathrm{l}^{-1}$ were observed off the Po river delta (Regione Emilia Romagna 1985, cited by Marchetti 1990).

Skeletonema costatum was grown under nitrate limitation in the chemostat cultures as nitrogen was found to be the nutrient limiting growth in the field during 1992. Nutrient limitation may be an important factor during aggregation. Kiørboe et al. (1990) showed that the stickiness of Thalassiosira pseudonata increased by 2 orders of magnitude as cell growth ceased and the diatom became nutrient limited. The stickiness of $S$. costatum was shown to be highest during the transition between the exponential and stationary growth phases (Kiørboe et al. 1990).

The aggregation of Skeletonema costatum with temperature increase may potentially explain the observed aggregation of diatom blooms in situ and subsequent sinking out of the water column. In this work 
the sinking rate of aggregated $S$. costatum was twice that of unaggregated cells. The aggregation of a diatom bloom associated with a temperature rise will lead to a rapid increase in the flux rate of organic carbon and other nutrients from the photic zone to deeper waters and the sea bed. In shallow sea ecosystems such as the Northern Adriatic the flux of aggregates to the sea bed may have a severe impact on the ecosystem, including bottom water anoxia and the death of benthic organisms (Marchetti 1990, Stachowitsch et al. 1990). The seasonal pulse of phytodetritus to the abyssal and the sea bed is recognised as a world-wide phenomena (Smith et al. 1996) of importance to the carbon cycle and the supply of fixed carbon to the vast areas of the abyssal plain. The temperature facilitated aggregation of diatoms into fast sinking aggregates may have an importance not only in coastal zones but also in the world ocean

Acknowledgements. The authors thank Graham J. C. Underwood and David J. Smith for their comments during the preparation of this manuscript.

\section{LITERATURE CITED}

Alldredge AL, Gotschalk CC (1989) Direct observations of diatom blooms: characteristics, settling velocities and formation of diatom aggregates. Deep-Sea Res 36(2):159-171

Alldredge AL, Passow V, Logan BE (1993) The abundance and significance of a class of large, transparent organic particles in the ocean. Deep-Sea Res 40(6):1131-1140

Alldredge AL, Silver MW (1988) Characteristics, dynamics and significance of marine snow. Prog Oceanogr 20:41-82

Bienfang PK (1981) SETCOL-a technologically simple and reliable method for measuring phytoplankton sinking rates. Can J Fish Aquat Sci 38: 1289-1294

Crocker KM, Passow U (1995) Differential aggregation of diatoms. Mar Ecol Prog Ser 117:249-257

Decho AW (1990) Microbial exopolymer secretions in ocean environments: their role(s) in food webs and marine processes. Oceanogr Mar Biol Annu Rev 28:78-153

FigP Sofware Corporation (1992) Fig.P, version 6.0c. Biosoft, Cambridge

Fogg GE, Thake B (1987) Algal cultures and phytoplankton ecology, 3rd edn. The University of Wisconsin Press, London

Fowler SW, Knauer GA (1986) Role of large particles in the transport of elements and organic compounds through the Oceanic water column. Prog Oceanogr 16:147-194

Grossart HP, Simon M (1993) Limnetic macroscopic organic aggregates (lake snow): occurrence, characteristics and microbial dynamics in Lake Constance. Limnol Oceanogr 38:532-546

Guillard, RRL (1973) Division rates. In: Stein JR (ed) Handbook of phycological methods: culture methods and growth measurements. Cambridge University Press, London, p 289-311

Han MS, Furuya K, Nemoto T (1992) Species-specific productivity of Skeletonema costatum (Bacillariophyceae) in the inner part of Tokyo Bay. Mar Ecol Prog Ser 79:267-273

Harrison PJ, Waters RE, Taylor FJR (1980) A broad spectrum artificial seawater medium for coastal and open ocean phytoplankton. J Phycol 16:28-35

Jackson GA (1995) Coagulation of marine algae. Adv Chem 244:203-217

Kiørboe T, Anderson KP, Dam HG (1990) Coagulation efficiency and aggregate formation in marine phytoplankton. Mar Biol 107:235-245

Kiørboe T, Hansen JLS (1993) Phytoplankton aggregate formation: observations of patterns and mechanisms of cell sinking and the significance of exopolymeric material. J Plankton Res 15:993-1018

Logan BE, Alldredge AL (1989) Potential for increased nutrient uptake by flocculating diatoms. Mar Biol 101:443-450

Marchetti R (1990) Algal blooms and gel production in the Adriatic sea. In: Barth H, Fegan L (eds) Water Research Report 16. Eutrophication phenomena in the Adriatic Sea and other Mediterranean coastal zones. Commission of the European Communities, Brussels, p 21-42

McCave IN (1984) Size spectra and aggregation of suspended particles in the deep ocean. Deep-Sea Res 31:329-352

Napier IR (1995) Growth and collapse of a spring phytoplankton bloom in the Firth of Clyde, Scotland. Mar Biol 123 189-195

Parsons TR, Maita Y, Lalli CM (1984) A manual of chemical and biological methods for seawater analysis. Pergamon Press, Oxford

Porter KG, Feig YS (1980) The use of DAPI for identifying and counting aquatic microflora. Limnol Oceanogr 25:943-948

Rees DG (1987) Foundations of statistics. Chapman and Hall, London

Riebesell U (1991a) Particle aggregation during a diatom bloom. I. Physical aspects. Mar Ecol Prog Ser 69:261-272

Riebesell U (1991b) Particle aggregation during a diatom bloom. II. Biological aspects. Mar Ecol Prog Ser 69: $281-291$

Santillo D (1993) Comparative chemostat studies with Synechococcus WH7803 and Pavlova lutheri. PhD thesis, University of London

Shanks AL, Reeder ML (1993) Reducing microzones and sulfide production in marine snow. Mar Ecol Prog Ser 96: $43-47$

Smetacek VS (1985) Role of sinking in diatom life-history cycles: ecological, evolutionary and geological significance. Mar Biol 84:239-251

Smith CR, Hoover DJ, Doan SE, Pope RH, Demaster DJ, Dobbs FC, Altabet MA (1996) Phytodetritus at the abyssal sea-floor across 10-degrees of latitude in the central equatorial Pacific. Deep-Sea Res II 43:1309-1338

Stachowitsch M, Fanuko N, Richter M (1990) Mucus aggregates in the Adriatic sea: an overview of stages and occurrences. PSZN I: Mar Ecol 11:327-350

SYSTAT Products (1997) SYSTAT, version 7.0. SPSS, Inc, Chicago

Tempest DW (1970) The continuous cultivation of microorganisms: I. Theory of the chemostat. In: Norris JR, Ribbons DW (eds) Methods in microbiology, Vol 2. Academic Press, London, p 259-276

Thornton DCO (1996) Growth, mucilage production and aggregation of Skeletonema costatum. PhD thesis, University of London

Wymer PEO, Thake B (1980) The importance of phosphorus in microalgal growth and species composition in mixed populations: experiments and simulations. Proc R Soc Lond B 209:333-353

Zar JH (1996) Biostatistical analysis, 3rd edn. Prentice-Hall, Englewood Cliffs, NJ 